\title{
PEMIKIRAN AL 'ADAWI TENTANG PENDIDIKAN AKHLAK ANAK SEBELUM KELAHIRANNYA
}

\author{
Ardian Al Hidaya \\ Dosen Tetap Sekolah Tinggi Agama Islam (STAI) Madiun
}

\section{Abstrak}

Pendidikan akblak merupakan hal yang sangat penting dan harus menjiwai segala bentuk pendidikan. Jika tidak, pendidikan akan hanya merupakan sesuatu yang sia-sia, bahkan akan menimbulkan mad\}arat di tengah-tengah kehidupan masyarakat. Mengenai sejak kapan seharusnya anak mendapat pendidikan khususnya pendidikan akblak, ada beberapa teori. Islam telah mengajarkan pendidikan anak sejak dini. Sejak dini yang dimaksud adalah semenjak ia masih dalam kandungan, ada juga yang mengartikan sejak dini adalah pada saat prosesi pembuahan, bahkan ada yang berpendapat jauh hari sebelum kedua orang tuanya menikah. Tulisan ini mencoba mengungkap pemikiran Muștafä al-'Adawi dalam karyanya: Fiqh Tarbiyyat al-Abnä' wa Täifah min Nașāh al-Ațibbä, namun penelaahannya khusus pada bagian pendidikan akblak sejak dini, yaitu pemikirannya mengenai peran hidayah dan doa dalam kaitannya dengan kelangsungan akblak anak, konsepnya tentang pendidikan orang tua terhadap anak sebelum dilahirkan. Hasil penelitian terhadap karya al-'Adawi ini mengungkapkan bahwa pendidikan akblak anak seharusnya sudah diselenggarakan sebelum anak itu terlahir dengan tetap "dibungkus" dengan ketaubidan yang tinggi. Karena tingkah laku, usaha dan kecenderungan orang tua, termasuk inisiatif dalam memilih jodoh yang saleh/ salehah, cara melakukan hubungan intim, ikhtiar orang tua selama anak dalam kandungan, bisa merupakan pendidikan yang juga 
berperan dalam membentuk akblak anak di kebidupannya nanti.

Kata Kunci: Pendidikan, akhlak, sejak dini

\section{A. Faktor Hidayah Dalam Kaitannya Dengan Akhlak Anak}

Mendidik anak dalam kitab iqh Tarbiyyat al-Abnā' wa Täifah min Nașāh al-Ațibbā, 'oleh al-'Adawi diawali dengan masalah hidayah/ petunjuk. Menurut pemikiran al-'Adawi, pendidikan anak khususnya akhlak merupakan tugas dan tanggung jawab orang tua. Akan tetapi, bagaimanapun usaha orang tua dalam mendidik anak, jika tidak mendapatkan hidayah Allah swt, maka usaha tersebut tidak akan memberikan pengaruh apapun. Sebagaimana diketahui, bagaimana usaha Nabi Nuh as mengajak anaknya untuk beriman kepada Allah, nabi Luth dengan ajakan kepada istrinya dan umatnya untuk menjauhi dosa, ajakan Nabi Muhammad kepada sebagian kerabatnya yang masih bersikukuh pada ajaran lamanya, kiranya cukup untuk menjadi bukti bahwa faktor hidayah menjadi hal terpenting untuk seseorang yang diharapkan kebaikannya di dunia dan akhirat. Pembahasan tentang hidayah dalam kitab ini didukung oleh begitu banyak ayat-ayat alQuran. Sebagaimana tertulis di bawah ini:

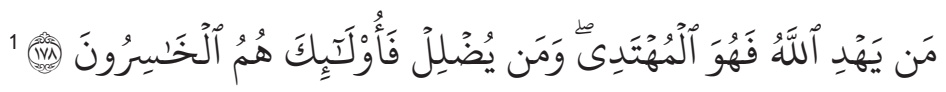

Barangsiapa yang diberi petunjuk oleh Allah, maka dialah yang mendapat petunjuk; dan barangsiapa yang disesatkan Allah, maka merekalah orangorang yang merugi.

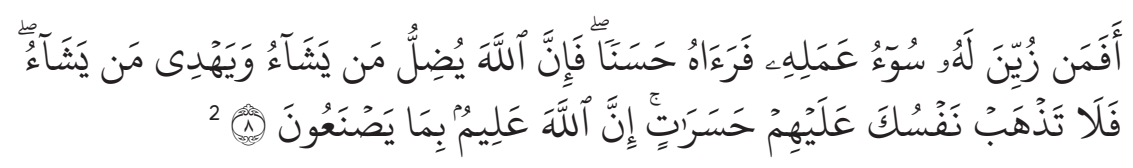

Maka apakah orang yang dijadikan (syaitan) menganggap baik pekerjaannya yang buruk lalu dia meyakini pekerjaan itu baik, (sama dengan orang yang tidak ditipu oleh syaitan)? Maka Sesungguhnya Allah menyesatkan siapa yang dikehendaki-Nya dan menunjuki siapa yang dikehendaki-Nya; Maka

\footnotetext{
1 al-Qur'an, 7: 178.

2 Ibid., 35: 8.
} 
janganlah dirimu binasa Karena kesedihan terhadap mereka. Sesungguhnya Allah Maha mengetahui apa yang mereka perbuat.

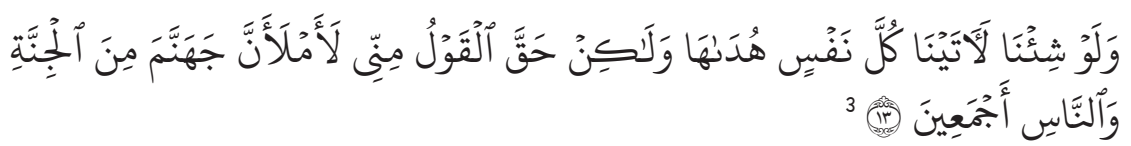

Dan kalau kami menghendaki niscaya kami akan berikan kepada tiaptiap jiwa petunjuk, akan tetapi Telah tetaplah perkataan dari padaKu: "Sesungguhnya akan Aku penubi neraka Jahannam itu dengan jin dan manusia bersama-sama."

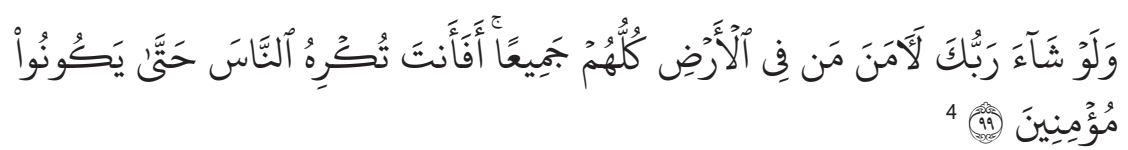

Dan jikalau Tuhanmu menghendaki, tentulah beriman semua orang yang di muka bumi seluruhnya. Maka apakah kamu (hendak) memaksa manusia supaya mereka menjadi orang-orang yang beriman semuanya?

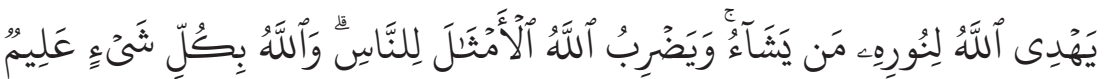

.... Allah membimbing kepada cahaya-Nya siapa yang dia kehendaki, dan Allah memperbuat perumpamaan-perumpamaan bagi manusia, dan Allah Maha mengetahui segala sesuatu.

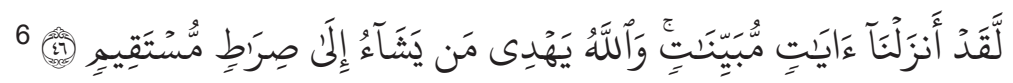

Sesungguhnya kami telah menurunkan ayat-ayat yang menjelaskan. dan Allah memimpin siapa yang dikehendaki-Nya kepada jalan yang lurus.

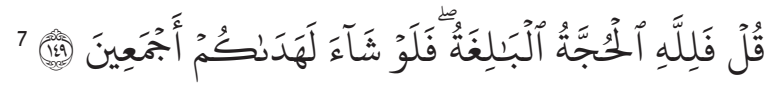

\footnotetext{
3 Ibid., 32: 13.

4 Ibid., 10: 99.

5 Ibid., 24: 35.

6 Ibid., 24: 46.

7 Ibid., 6: 149.
} 
Katakanlah: "Allah mempunyai hujjah yang jelas lagi kuat; Maka jika Dia menghendaki, pasti dia memberi petunjuk kepada kamu semuanya".

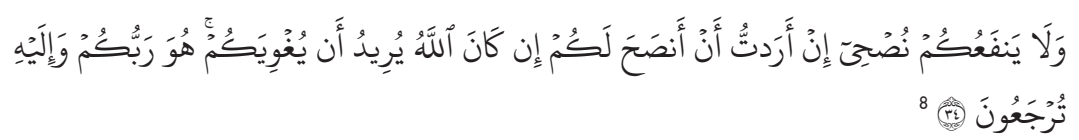

Dan tidaklah bermanfaat kepadamu nasehatku jika Aku hendak memberi nasehat kepada kamu, sekiranya Allah hendak menyesatkan kamu, dia adalah Tuhanmu, dan kepada-Nya-lah kamu dikembalikan".

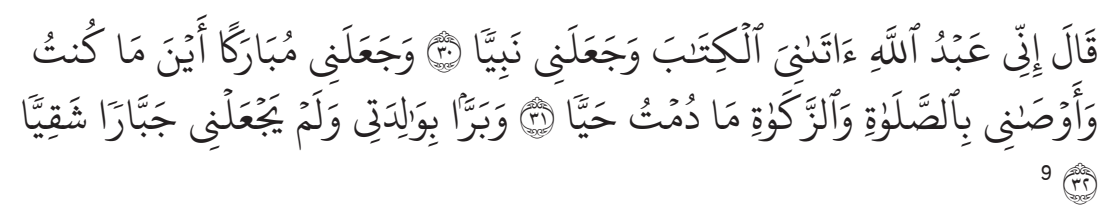

(Berkata Isa): "Sesungguhnya Aku Ini hamba Allah, dia memberiku Al Kitab (Injil) dan dia menjadikan aku seorang nabi,

Dan dia menjadikan aku seorang yang diberkati di mana saja aku berada, dan dia memerintahkan kepadaku (mendirikan) shalat dan (menunaikan) zakat selama aku hidup;

Dan berbakti kepada ibuku, dan dia tidak menjadikan aku seorang yang sombong lagi celaka.

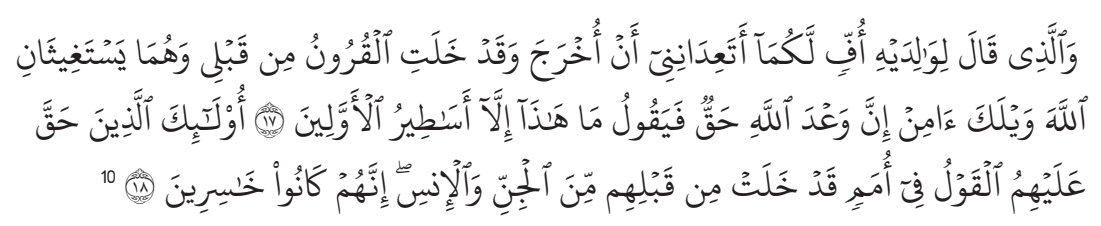

Dan orang yang berkata kepada dua orang ibu bapaknya: "Cis bagi kamu berdua, apakah kalian berdua memperingatkan kepadaku bahwa aku akan dibangkitkan, padahal sungguh telah berlalu beberapa umat sebelumku? lalu kedua ibu bapaknya itu memohon pertolongan kepada Allah seraya mengatakan: "Celaka kamu, berimanlah! Sesungguhnya janji Allah adalah benar". Lalu dia berkata: "Ini tidak lain hanyalah dongengan orang-orang dahulu belaka".

\footnotetext{
${ }^{8}$ Ibid., 11: 34.

9 Ibid., 19: 30-32.

${ }^{10}$ Ibid., 46: 17-18.
} 
Mereka Itulah orang-orang yang telah pasti ketetapan (azab) atas mereka bersama umat-umat yang telah berlalu sebelum mereka dari jin dan manusia. Sesungguhnya mereka adalah orang-orang yang merugi.

Pembahasan tentang hidayah dalam kitabnya tersebut ternyata begitu menggelisahkan al-'Adawi, sehingga ia segera berdoa:

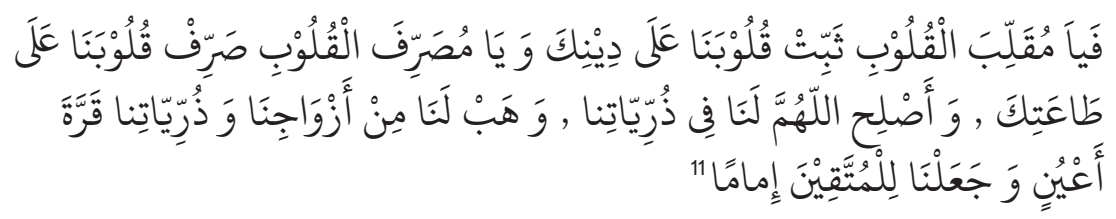

Wahai yang membolak-balikkan hati, tetapkanlah hati kami pada agama-Mu, Wahai yang memalingkan hati, bimbinglah hati kami kepada ketaatan, ya Allah, baguskanlah akhlaq keturunan kami, jadikanlah istri dan anak-anak kami menjadi penyejuk hati dan pandangan, dan jadikanlah kami imam orang-orang yang bertaqwa.

\section{B. Para Nabi pun Tidak Sanggup Memberikan Hidayah}

Pemikiran al- 'Adawi yang menyatakan bahwa petunjuk itu mutlak dari Allah swt, dipertegas juga dalam pernyataannya yang lain bahwa para nabi dan rasulpun tidak sanggup memberi hidayah, walaupun pada keluarganya sendiri. Dia menampilkan ayat-ayat al-Quran seperti berikut ini:

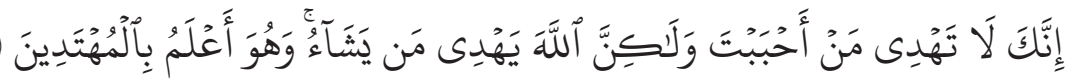

Sesungguhnya kamu (Muhammad) tidak akan dapat memberi petunjuk kepada orang yang kamu kasibi, tetapi Allah memberi petunjuk kepada orang yang dikehendaki-Nya, dan Allah lebih mengetahui orang-orang yang mau menerima petunjuk.

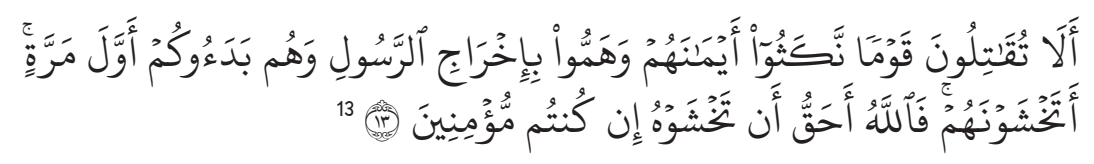

\footnotetext{
${ }^{11}$ Abu 'Abdillah Mușțafā al-'Adawi, Fiqh Tarbiyyat al-Abnā' wa Täifah min Nașāh al-Ațibbā, (Jeddah : Dār Mājid 'Asiri,1998), 8.

${ }^{12}$ al-Qur'an, 28: 56.

${ }^{13}$ Ibid, 9: 113.
} 
Tiadalah sepatutnya bagi nabi dan orang-orang yang beriman memintakan ampun (kepada Allah) bagi orang-orang musyrik, walaupun orang-orang musyrik itu adalah kaum kerabat (nya), sesudah jelas bagi mereka, bahwasanya orang-orang musyrik itu adalah penghuni neraka jahanam.

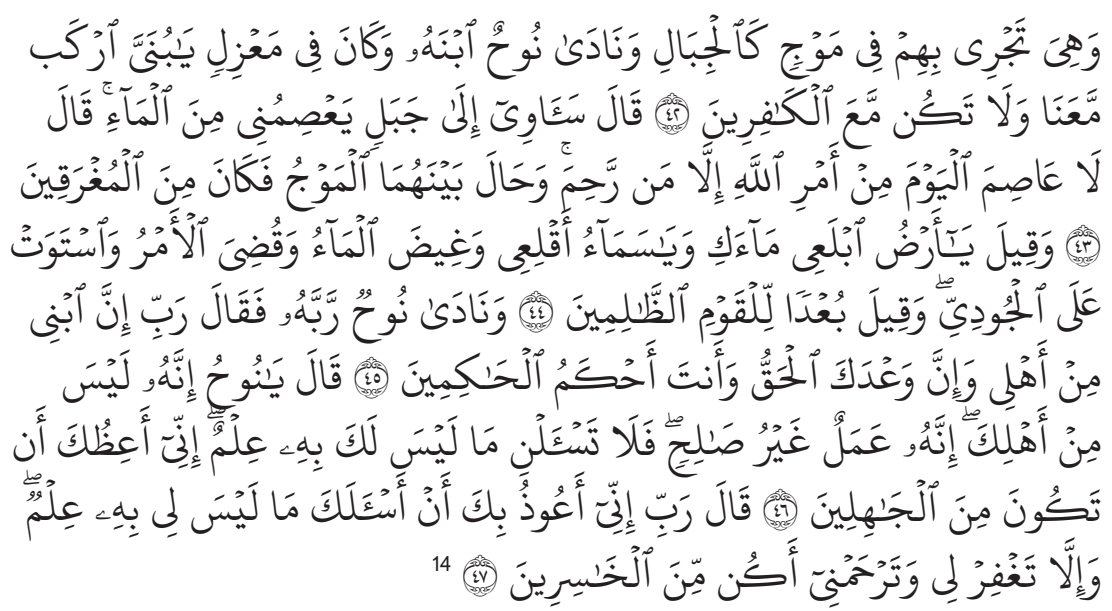

Dan bahtera itu berlayar membawa mereka dalam gelombang laksana gunung. dan Nuh memanggil anaknya, sedang anak itu berada di tempat yang jauh terpencil: "Hai anakku, naiklah (ke kapal) bersama kami dan janganlah kamu berada bersama orang-orang yang kafir."

Anaknya menjawab: "Aku akan mencari perlindungan ke gunung yang dapat memeliharaku dari air bah!" Nuh berkata: "Tidak ada yang melindungi hari Ini dari azab Allah selain Allah (saja) yang Maha penyayang". dan gelombang menjadi penghalang antara keduanya; Maka jadilah anak itu termasuk orang-orang yang ditenggelamkan.

Dan difirmankan: "Hai bumi telanlah airmu, dan Hai langit (bujan) berhentilah," dan airpun disurutkan, perintahpun diselesaikan dan bahtera itupun berlabuh di atas bukit Judi, dan dikatakan: "Binasalah orang-orang yang zalim."

Dan Nuh berseru kepada Tuhannya sambil berkata: "Ya Tuhanku, Sesungguhnya anakku termasuk keluargaku, dan Sesungguhnya janji Engkau Itulah yang benar. dan Engkau adalah hakim yang seadil-adilnya."

Allah berfirman: "Hai Nuh, Sesungguhnya dia bukanlah termasuk

${ }^{14}$ Ibid., 11: 42- 47. 
keluargamu (yang dijanjikan akan diselamatkan), Sesungguhnya (perbuatan) nya perbuatan yang tidak baik. sebab itu janganlah kamu memohon kepadaKu sesuatu yang kamu tidak mengetahui (hakekat)nya. Sesungguhnya Aku memperingatkan kepadamu supaya kamu jangan termasuk orang-orang yang tidak berpengetahuan."

Nuh berkata: Ya Tuhanku, Sesungguhnya Aku berlindung kepada Engkau dari memohon kepada Engkau sesuatu yang Aku tiada mengetahui (hakekat) nya. dan sekiranya Engkau tidak memberi ampun kepadaku, dan (tidak) menaruh belas kasihan kepadaku, niscaya Aku akan termasuk orang-orang yang merugi."

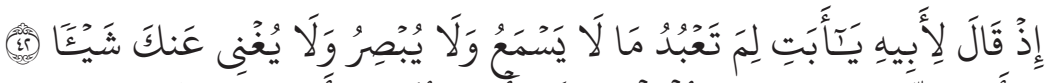

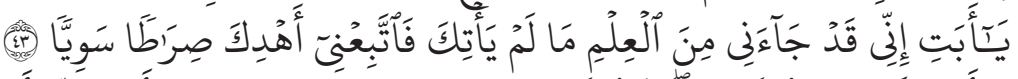

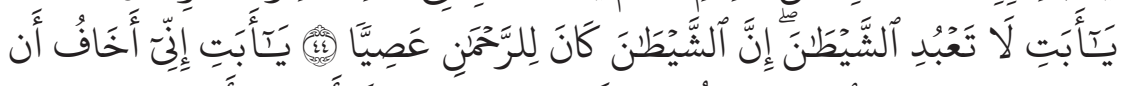

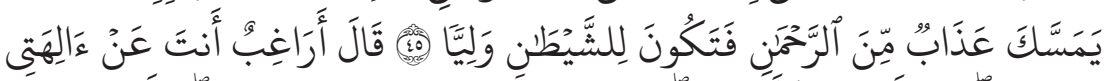

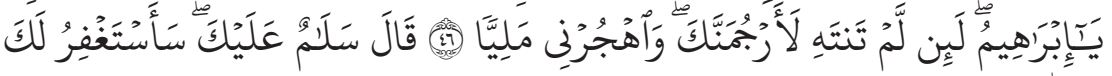

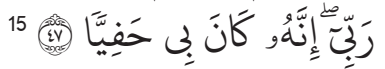

Ingatlah ketika ia berkata kepada bapaknya; "Wahai bapakku, mengapa kamu menyembah sesuatu yang tidak mendengar, tidak melihat dan tidak dapat menolong kamu sedikitpun?

Wahai bapakku, sesungguhnya telah datang kepadaku sebahagian ilmu pengetahuan yang tidak datang kepadamu, Maka ikutilah aku, niscaya aku akan menunjukkan kepadamu jalan yang lurus.

Wahai bapakku, janganlah kamu menyembah setan. Sesungguhnya setan itu durhaka kepada Tuhan Yang Maha Pemurah.

Wahai bapakku, sesungguhnya aku khawatir bahwa engkau akan ditimpa azab dari Tuhan yang Maha pemurah, maka kamu menjadi kawan bagi setan".

Berkata bapaknya: "Bencikah kamu kepada tuhan-tuhanku, hai Ibrahim? jika kamu tidak berhenti, maka niscaya kamu akan kurajam, dan tinggalkanlah aku buat waktu yang lama".

15 Ibid, 19: 42-45. 
Uraian panjang lebar ayat-ayat di atas sungguh jelas menerangkan bahwa seorang nabi tidak akan bisa memberikan hidayah, termasuk nabi Ibrahim as. Ia tidak kuasa memberikan petunjuk pada orang lain, bahkan pada keluarganya, dalam hal ini pada ayahnya sendiri. Padahal sebelumnya beliau sudah memberikan banyak argumen rasional sebelum mengajak ayahnya untuk bertauhid.

Meskipun bahasa Nabi Ibrahim as sudah diperhalus, namun terkesan ada penekanan dan rasa antusias untuk memberikan pencerahan atau petunjuk pada ayahnya. Hal ini dapat dimaklumi, karena tindakan ayahnya dianggap sudah melenceng jauh dari agama tauhid dan Nabi Ibrahim as sangat mengkhawatirkan keselamatan ayahnya di akhirat. Sekaligus ini bukti cinta dan sayang beliau pada ayahnya, jauh dari suatu bentuk kedurhakaan pada orang tuanya.

Justru ketika beliau di kemudian hari berdialog dengan sang putera, yakni Ismail as, terkait masalah mimpi beliau untuk menyembelih putera kesayangannnya tersebut, dengan tidak banyak argumen bahkan dengan pemberitaan yang bernada datar dan tawaran/pertanyaan yang bersifat opsional, Imail as justru memberikan jawaban yang mencerminkan bahwa ia termasuk manusia yang mendapat petunjuk dari Allah swt. Mari kita perhatikan ayat berikut ini:

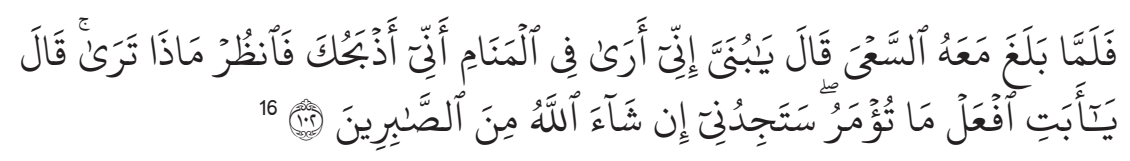

Maka tatkala anak itu sampai (pada umur sanggup) berusaha bersama-sama Ibrahim, Ibrahim berkata: "Hai anakku Sesungguhnya Aku melihat dalam mimpi bahwa Aku menyembelihmu. Maka fikirkanlah apa pendapatmu!" ia menjawab: "Hai bapakku, kerjakanlah apa yang diperintahkan kepadamu; insya Allah kamu akan mendapatiku termasuk orang-orang yang sabar".

Itulah bukti bahwa seorang nabi, dalam hal ini dicontohkan dengan keberadaan Nabi Ibrahim as, tidak akan mampu memberikan hidayah pada manusia, sekalipun pada keluarganya. Jangankan nabi, malikatpun juga tidak kuasa memberikan petunjuk (kisah Jibril as dan Musa Samiri). Allah lah yang memberi petunjuk pada hamba yang dikehendaki-Nya. Namun, perlu ditegaskan, bahwa jika sesorang itu tersesat, bukan berarti

${ }^{16}$ Ibid., 37: 102 . 
Allah berlaku zalim pada hamba-Nya, melainkan hamba-Nya tersebutlah yang telah menzalimi dirinya sendiri. Itulah mengapa al-Adawi selanjutnya mengutip ayat berikut ini:

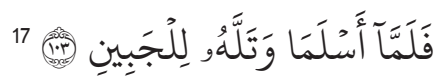

Kami limpahkan keberkatan atasnya dan atas Ishaq. dan di antara anak cucunya ada yang berbuat baik dan ada (pula) yang zalim terhadap dirinya sendiri dengan nyata.

\section{Tidak Akan Ada Yang Bisa Menyesatkan Seseorang Jika Seseorang Itu Mendapat Hidayah Allah SWT}

Setelah membahas tentang urgensi faktor hidayah, para Nabi dan Rasul tidak sanggup memberi hidayah, selanjutnya al- Adawi menyatakan bahwa jika seseorang itu telah ditakdirkan mendapat hidayah, maka tak satupun makhuk yang dapat menyesatkannya, walaupun oleh orang-orang dekatnya atau keluarganya. Hal ini dijelaskan al-'Adawi dengan menampilkan kisahkisah dalam al-Quran, yaitu kisah Nabi Yusuf di lingkungan saudarasaudaranya yang menempuh jalan kesesasatan, bagaimana juga kisah Nabi Musa as yang diasuh oleh Fir'aun yang kafir, dan terlebih kisah Nabi Muhammad saw yang semasa kecil sudah dalam keadaan yatim piatu, fakir dan dikelilingi oleh orang-orang musyrik dan kafir yang memusuhinya, bahkan sebagian dari mereka adalah kerabat dekat beliau sendiri. Siapakah yang memberi petunjuk pada beliau-beliau? Siapa yang menumbuhkan iman dan menjaga iman beliau-beliau?

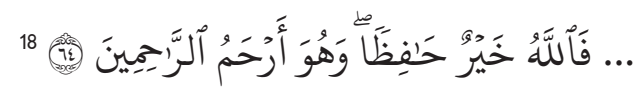

... Maka Allah adalah sebaik-baik Penjaga dan dia adalah Maha Penyanyang diantara para penyanyang.

Seluruh pembahasan di atas bukan bermaksud untuk bertindak pasif dan mengikut paham fatalis (Jabbāriyyah) di mana akhirnya manusia bersikap acuh tak acuh tehadap pendidikan anak terutama akhlak. Menurut penulis, al- 'Adawi ingin menjelaskan tentang pentingnya bertauhid dalam

\footnotetext{
${ }^{17}$ Ibid., 37: 113.

${ }^{18}$ Ibid, 12 (Yūsuf) : 64.
} 
mendidik anak dan menempatkan manusia dalam posisi yang semestinya, yakni sebagai hamba Allah yang tetap berusaha dan selalu menyandarkan segala hasilnya pada Allah, dan agar tidak terjebak dalam faham Qadariyyah, di mana menurut faham ini, manusialah yang menentukan baik buruknya akhlak manusia lain. Hal ini secara eksplisit diungkapkan oleh al-'Adawi:

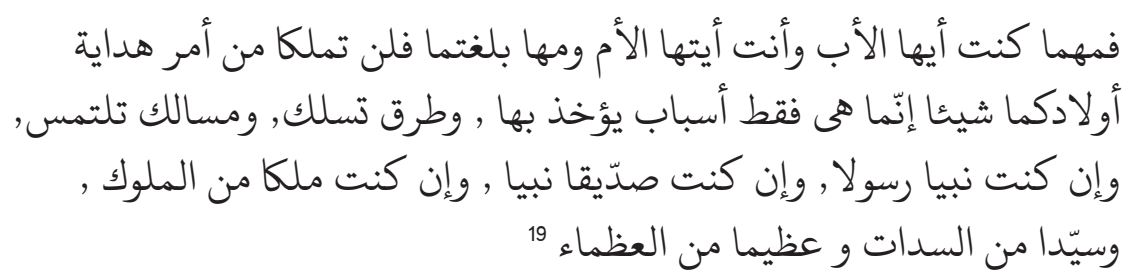

Jadi, siapapun anda berdua, wahai bapak dan ibu, dan sekeras apapun usaha anda untuk memberikan hidayah kepada anak-anak anda, tidak akan berhasil jika tidak dikehendaki oleh Allah swt, sekalipun anda seorang rasul atau nabi, sekalipun anda seorang siddiq, sekalipun anda raja atau pembesar lainnya. Apa yang anda lakukan itu hanyalah sematamata sebab yang wajib anda usahakan, jalan yang harus Anda tempuh. (Adapun hasilnya, maka serahkan kepada Allah).

Menurut penulis, kisah-kisah dalam al-Quran di atas, adalah sebagai 'ibrah/pelajaran yang sangat berharga bagi kita umat manusia sebagai berikut:

1. Kisah Nabi Nuh dan anaknya Kan'an, pelajaran bahwa kita tidak seharusnya mendewa-dewakan nasab yang hal seperti ini jelas meracuni ketauhidan kita pada Allah swt. Orang tua yang saleh mungkin saja mempunyai anak yang durhaka.

2. Kisah Nabi Ibrahim dan ayahnya, Azar, pelajaran bahwa kita tidak boleh pesimis jika orang tua kita misalnya termasuk orang yang durhaka, karena sifat pesimis atau putus asa jelas-jelas dilarang dalam Islam. Pelajaran ini berguna pula jika kita kebetulan seorang pendidik ketika menghadapi anak didik dari keturunan orang tua yang durhaka, karena masih ada kemungkinan dari orang durhaka akan lahir anak yang saleh dengan suatu sebab yang kadang sulit manusia mengerti.

${ }^{19}$ Abu 'Abdillah Mușțafā al-'Adawi, Fiqh Tarbiyyat al-Abnā' 
3. Kisah Musa as yang diasuh Fir'aun dan Musa Samiri yang diasuh malaikat Jibril as, pelajaran bahwa kita tidak seharusnya mendewadewakan pendidikan, karena hal ini sebagaimana poin pertama di atas, akan meracuni ketauhidan kita pada Allah swt.

Hal di atas bukan berarti kita menganggap remeh masalah nasab dan pendidikan. Penulis menganggap bahwa dalam al-Quran yang berupa pesan kisah-kisah Nabi di atas adalah lebih kepada larangan mempunyai sifat sombong dan putus asa. Adapun mengenai usaha keras berupa mengupayakan nasab yang luhur dan memberikan pendidikan yang ideal, harus tetap dilakukan dengan tetap dilandasi keadaan batin yang dipenuhi al-Khauf dan al-Rajä' (kekhawatiran dan pengharapan).

Meskipun hidayah ini mutlak hak Allah yang diberikan pada hambNya yang dikendaki-Nya, namun karena dunia ini diberlakukan oleh-Nya hukum sebab akibat, maka seharusnyalah kita menempuh sebab-sebab yang sekiranya hidayah Allah bisa turun. Bahkan, kalau kita mencermati al-Quran surah al-Baqarah di bawah ini, sebetulnya hidayah itu turun setiap saat, tinggal manusianya saja yang mau atau enggan menyongsong dan mendapatkan hidayah tersebut:

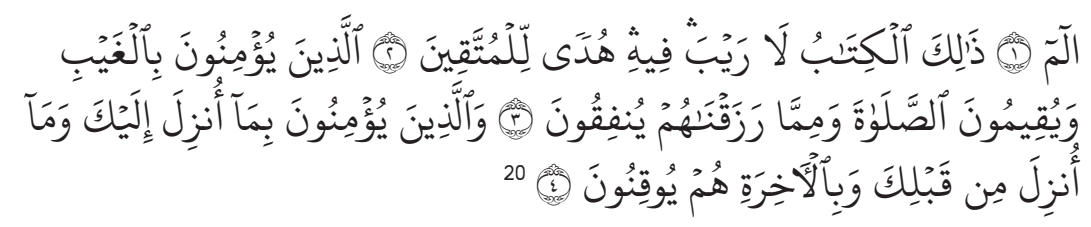

Alif laam miim

Kitab (Al Quran) ini tidak ada keraguan padanya; petunjuk bagi mereka yang bertaqwa

(yaitu) mereka yang beriman kepada yang ghaib, yang mendirikan shalat, dan menafkahkan sebahagian rezki yang kami anugerahkan kepada mereka.

Dan mereka yang beriman kepada Kitab (Al Quran) yang telah diturunkan kepadamu dan kitab-kitab yang telah diturunkan sebelummu, serta mereka yakin akan adanya (kehidupan) akbirat.

Jadi sebenarnya petunjuk itu telah turun, yaitu berupa al-Quran. Orang yang mendapatkan petunjuk adalah mereka yang telah menyandang predikat al-Muttaqien, orang-orang yang beriman kepada yang ghaib,

${ }^{20}$ al-Qur'an, 2: 1- 4 . 
yang mendirikan shalat, dan menafkahkan sebahagian rezki yang Allah anugerahkan kepada mereka. Juga mereka yang beriman kepada Kitab (Al Quran) dan juga yakin akan adanya (kehidupan) akhirat.

Jadi jika seseorang bertanya bagaimana diketahui bahwa seseorang itu diberi petunjuk, maka jawabnya adalah ketika seseorang itu sudah tergolong orang yang muttaqien. Maka hal ini diharapkan agar kita senantiasa introspeksi diri agar melakukan perbaikan diri di setiap waktu menjadi orang yang muttaqien. Hal menarik juga diungkapkan oleh seorang ulama nusantara, Syeikh Nawawi bin 'Umar al- Bantani :

$$
\begin{aligned}
& \text { (وإنما هذه الطاعات والمعاصى علامات على الإثابة) أى إثابة الله تعالى بالثواب }
\end{aligned}
$$

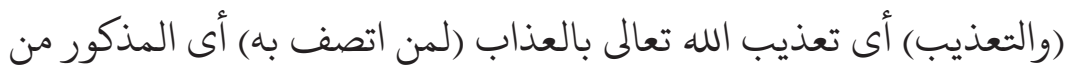

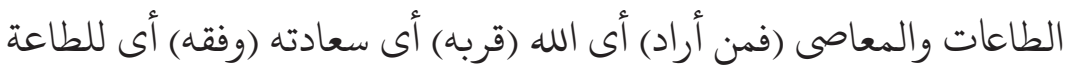

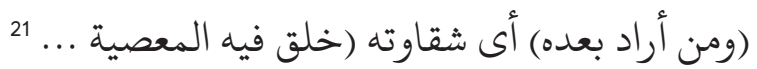

Sesungguhnya ketaatan dan kemaksiatan seorang hamba adalah merupakan pertanda bahwa Allah sedang memberikan pahala atau siksa pada hamba tersebut. Ketika seorang hamba dikehendaki dekat dengan-Nya (mendapatkan kebahagiaan), maka akan dianugerahi-Nya hamba tersebut taufiq untuk taat pada-Nya. Dan sebaliknya, ketika seorang hamba dikehendaki jauh dari-Nya (celaka), maka diciptakan pada dirinya kemaksiataan...

\section{Peran Doa Dan Usaha Batin dalam Memperoleh Keturunan Yang Saleh}

Setelah membahas masalah hidayah, al-'Adawi melanjutkan dengan pembahasan doa agar dikaruniai keturunan saleh. Bahwa Nabi saw seringkali mendoakan keturunannya dan juga keturunan para sahabat agar menjadi keturunan yang saleh/ salehah. Nabi-nabi dan rasul sebelum beliaupun, juga mendoakan keturunan mereka, sebagaimana yang dijelaskan dalam ayat-ayat al-Quran:

${ }^{21}$ Muhammad Nawawi bin 'Umar al-Jawi al-Shafi'i, Fath al-Majìd fì Sharh al-Durr al-Farìd (Dār Ihyā̄a al-Kutub al-Arabiyyah), 38. Dalam pembahasan selanjutnya, Syekh Nawawi menjelaskan bahwa pada hakekatnya seluruh tindakan manusia, baik atau buruk, gerak tubuh yang bersifat ikhtiyar dan yang bersifat otomatis, semuanya diciptakan oleh Allah. Hanya saja menisbatkan hal-hal buruk pada Allah, itu seyogyanya tidak dilakukan, demi menjaga akhlak kita pada Allah. 


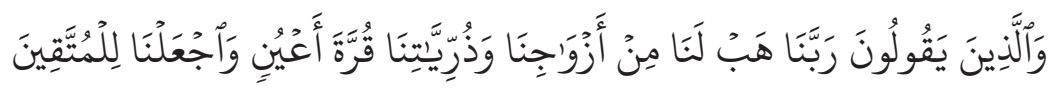

22 (إِمَامَا

Dan orang orang yang berkata: "Ya Tuhan kami, anugerahkanlah kepada kami isteri-isteri kami dan keturunan kami sebagai penyenang hati dan jadikanlah kami imam bagi orang-orang yang bertakwa.

Nabi Zakaria as pernah berdoa:

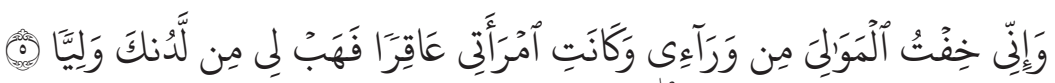

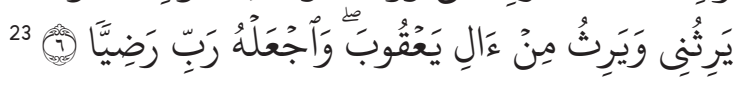

Dan sesungguhnya aku khawatir terhadap mawaliku sepeninggalku, sedang isteriku adalah seorang yang mandul, maka anugerahilah aku dari sisi Engkau seorang putera,

Yang akan mewarisiku dan mewarisi sebahagian keluarga Ya'qub; dan jadikanlah ia, Ya Tuhanku, manusia yang Engkau ridhai".

Beliau juga berdoa:

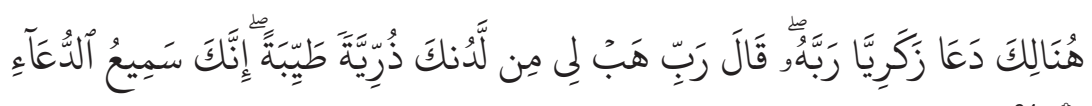

Di sanalah Zakariya mendoa kepada Tuhannya seraya berkata: "Ya Tuhanku, berilah aku dari sisi Engkau seorang anak yang baik. Sesungguhnya Engkau Maha Pendengar Doa".

Nabi Ibrahim as berdoa:

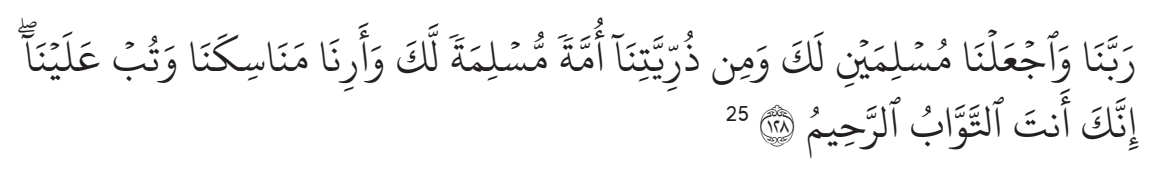

Ya Tuhan kami, jadikanlah kami berdua orang yang tunduk patuh kepada Engkau dan (jadikanlah) di antara anak cucu kami umat yang tunduk patuh

\footnotetext{
${ }^{22}$ al-Qur'an, 25: 74

${ }_{23}$ Ibid., 19: 5-6.

${ }^{24}$ Ibid., 3: 38.

25 Ibid., 2: 128.
} 
kepada Engkau dan tunjukkanlah kepada kami cara-cara dan tempat-tempat ibadat haji kami, dan terimalah taubat kami. Sesungguhnya Engkaulah yang Maha Penerima Taubat lagi Maha Penyayang.

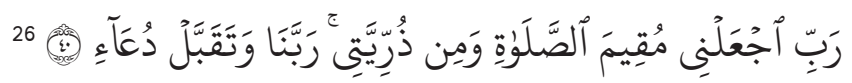

Ya Tuhanku, jadikanlah aku dan anak cucuku orang-orang yang tetap mendirikan shalat, Ya Tuhan kami, perkenankanlah doaku.

Seluruh ayat yang ditampilkan al-Adawi di atas semuanya tentang doa Nabi memohon keturunan yang saleh. Walaupun dalam ayat-ayat di atas tidak ada lafaz " صلح "atau padanannya yang menunjuk arti saleh/ kesalehan, namun semuanya dapat dikategorikan pada arti saleh/kesalehan, karena ayat-ayat di atas tentang doa mohon keturunan yang diridhai, baik, tunduk pada Tuhan dan mendirikan shalat.

Adapun ayat yang secara lafaz jelas-jelas menunjuk pada lafaz" صلح " atau padanannya, dapat dilihat pada dua contoh ayat di bawah ini, yaitu doa Nabi Ibrahim As :

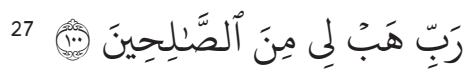

Ya Tuhanku, anugerahkanlah kepadaku anak-anak yang saleh.

Juga doa yang diucapkan oleh orang yang telah mencapai usia 40 ini :
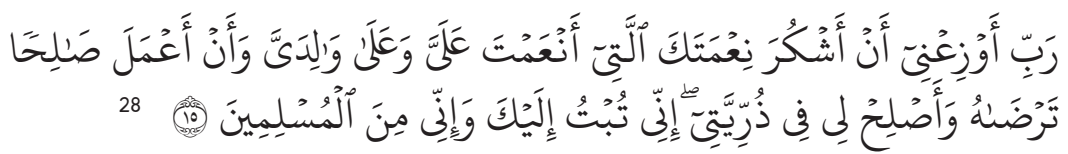

"...Ya Tuhanku, tunjukilah aku untuk mensyukuri nikmat-Mu yang telah Kau berikan kepadaku dan kepada ibu bapakku dan agar aku dapat berbuat amal yang saleh yang Engkau ridhai; berilah kebaikan kepadaku dengan (memberi kebaikan) kepada anak cucuku. Sesungguhnya Aku bertaubat kepada Engkau dan Sesungguhnya Aku termasuk orang-orang yang berserah diri".

\footnotetext{
${ }^{26}$ Ibid., 14: 40.

${ }^{27}$ Ibid., $37: 100$.

${ }^{28}$ Ibid., 46: 15 .
} 
Setiap manusia ketika masih di alam arwah sebenarnya sudah diberi bekal menyaksikan Allah (Shuhūd) sebagai al-Fitrah al-Imāniyyah. Setelah masuk ke rahim ibu, al-Fitrah al-Imāniyyah ini hendaknya tetap dijaga agar tetap murni dan bersih. Cara menjaganya adalah dengan tetap menjaga agar hati orangtua tetap bersih, mempunyai Safā al-Qalb. Imam Syafi'i yang ayahnya terkenal wira'i, menuturkan,bahwa jika seseorang menginginkan mempunyai anak saleh, maka syarat pertama yang harus dimiliki orang tua adalah: Șafā al-Qalb. Jika hati orang tua tidak bersih, semisal memiliki sifat hasad, tidak punya rasa malu dan ketika melakukan hubungan suami istri belum bertaubat dan berinisiatif memperbaiki diri, maka besar kemungkinan jika mempunyai anak hasil dari hubungan itu, maka anaknya mempunyai sifat hasad dan tidak punya rasa malu. Syarat kedua adalah al-Zäd al Halāl, makanan yang dikonsumsi sehari-harinya adalah makakan halal. Ketiga, Du'ā al-Walidain, doa kedua orang tua. Mengenai doa orang tua, ada kisah bahwa Kyai Șadiq bin Muṣlị̣ asal Tegaron Prambon Nganjuk, seorang yang Ulama kharismatik, selama ibunya mengandung, selalu melakukakn puasa. KH. Abdul Djalil bin Mustaqiem murshid tarekat Shadhiliyyah asal Tulungagung pernah berwasiat, bahwa jika istri mengandung, sang suami dianjurkan puasa minimal Senin-Kamis, dan setiap malam minimal membaca surah Yasin minimal 3 kali. Kyai Abdul Wahab Chasbullah, penggagas dan penggerak Jam'iyyah Nahdlatul Ulama, konon sang ibu selama mengandung selalu berpuasa. Sedangkan ayahnya, Kyai Chasbullah, ketika menikahi Nyai Lathifah (ibu Kyai Abd.Wahab), maharnya adalah mengkhatamkan al-Qur'an sebanyak 99 kali. Hingga Nyai Lathifah ketika mengandung pernah bermimpi meminum air samudra yang luas hingga habis. Ini semua dapat dikategorikan sebagai usaha batin dan doa dan demi menjaga al-fitrah al-imäniyyah ${ }^{29}$

Begitu pula kisah kelahiran Hadratus Syekh KH. Hasyim Asy'ari pendiri PP. Tebuireng, tokoh sentral NU yang juga kakek dari mantan Presiden RI ke-4, Gus Dur. Sebelum lahir, tanda-tanda Khäriq al-'̄Adah telah tampak pada jabang bayi Hadratus Syekh. Beliau berada dalam kandungan sang ibu selama 14 bulan. Masyarakat Jawa kala itu memiliki keyakinan bahwa masa kandungan yang panjang mengindikasikan kecemerlangan sang

\footnotetext{
${ }^{29}$ M. Djamaluddin Achmad, "Hikmah ke-267", dalam Kajian Rutin Sharh al-Hikam li ibn Ațaillah al-Sakandary, Jombang, 27 April 2009.
} 
bayi di masa depan. Sang ibu lebih yakin akan isyarat ini, karena dirinya pernah bermimpi melihat bulan purnama jatuh dari langit tepat menngenai perutnya yang sedang mengandung. Ketika mimpi ini diceritakan kepada sang suami, beliau tidak tahu persis apa yang akan terjadi. Namun beliau pernah mendengar bahwa mimpi semacam ini merupakan pertanda anugerah dari Allah swt. Pada masa mengandung pula, Nyai Halimah menjalankan berbagai macam riyādah (Jawa: tirakat) sebagi jembatan mendekatkan diri kepada Sang Khalik. Beliau senantiasa berpuasa di sepanjang hari, shalat malam tanpa henti serta tak lupa membaca al-Qur'an. Suatu hari, ketika sedang menampi beras, Ny. Halimah mendapati berasnya berubah wujud menjadi emas. Lantas beliau bergegas melaksanakan shalat Duhā. Setelah shalat beliau berdoa yang kurang lebih artinya: "Ya Allah, saya tidak meminta harta, saya hanya meminta kepada-Mu agar anak keturunan saya menjadi orang-otrang yang baik dan berguna bagi agama-Mu”. Akhirnya, pada hari Selasa Kliwon tangal 14 Februari $1871 \mathrm{M}$, yang bertepatan dengan 24 Dhul Qa'dah $1287 \mathrm{H}$, bayi yang ditunggu-tunggu ini akhirnya lahir dengan membawa suasana gembira di pondok Gedang, sebuah pondok yang masyhur kala itu, terletak di desa Tambakrejo, bersebelahan dengan desa Tambakberas, kurang lebih $2 \mathrm{~km}$ dari kota Jombang. Bayi istimewa itu, kemudian diberi nama Muhammad Hasyim. Kelak beliau terkenal dengan nama Had\{rat al-Shaikh Muhammad Hasyim Asy'ari. Nama yang dibelakang ini adalah nama ayahnya, Kiai Asy'ari, yang konon masih keturunan Jaka Tingkir. ${ }^{30}$ Selain kisah-kisah di atas, kiranya masih banyak lagi kisah-kisah yang menceritakan usaha batin dan do'a yang dilakukan oleh orang tua demi cita-citanya memiliki anak yang saleh dan salehah.

\section{E. Pengaruh Kebaikan Dan Amal Saleh Orang Tua Terhadap Pendidikan Anak}

Bahwa memang benar, tidak selalu orang tua yang saleh pasti mempunyai anak yang saleh, orang tua yang tidak saleh pasti mempunyai anak yang tidak saleh pula. Bisa jadi orang tua yang saleh memiliki anak yang tidak saleh, dan orang tua yang tidak saleh memiliki anak yang saleh,

${ }^{30}$ Redaksi www.NUbatik.net - PCNU Kota Pekalongan, "Mengenal lebih dekat dengan pendiri Nahdlatul Ulama,"dalam: http://www.nubatik.net/content/view/256/106/ (Selasa, 03 Maret 2009). 
terbukti dengan contoh-contoh kisah dalam al-Quran ataupun kisah-kisah yang beredar di masyarakat, tapi itu hanyalah beberapa saja dan tujuannya lebih kepada pengajaran tauhid kepada manusia, bahwa jangan memastikan sesuatu yang bukan hak kita memastikannya. Manusia sesungguhnya tidak akan mampu memastikan suatu perkara, karena seluruh perkara itu dalam kekuasaan Allah. Allah lah yang menghendaki dan berkuasa atas segala sesuatu.

Hal di atas cukup menjadi keyakinan dalam hati, adapun dalam pelaksanaannya, manusia sebagai Khalīfah fi al-Ard yang dianugerahi segala potensi tidak boleh berpangku tangan menunggu takdir dan keputusan Allah Yang Maha Berkehendak. Ia harus tetap berusaha dengan terus berproses menjadi manusia yang saleh, agar kemudian mendapatkan keturunan yang saleh pula, karena orang tua saleh yang kemudian mempunyai anak-anak yang saleh, lebih banyak kita jumpai. Inilah sunnatullah, hukum alam / kebiasaan. Hukum alam memang belum ada jaminan akan kepastiannya, akan tetapi tidak bijak jika kita berspekulasi dengan memilih menjadi manusia yang membiarkan diri dalam kubang kedurhakaan kepada Tuhan. Kiranya akan lebih selamat jika kita memilih jalan orang-orang muttaqien, orang-orang yang akhirnya mendapat petunjuk. Menjadi saleh merupakan suatu pilihan, sebagaimana menjadi manusia beriman, adalah merupakan sebuah pilihan. Allah berfirman :

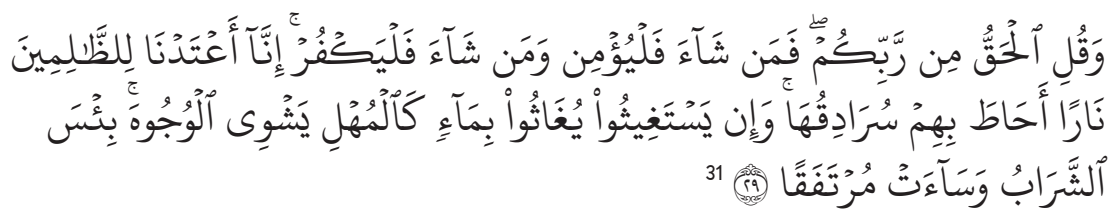

Dan Katakanlah: "Kebenaran itu datangnya dari Tuhanmu; Maka barangsiapayang ingin (beriman) hendaklah ia beriman, dan barangsiapa yang ingin (kafir), biarlah ia kafir". Sesungguhnya kami telah sediakan bagi orang orang zalim itu neraka, yang gejolaknya mengepung mereka. dan jika mereka meminta minum, niscaya mereka akan diberi minum dengan air seperti besi yang mendidih yang menghanguskan muka. Itulah minuman yang paling buruk dan tempat istirahat yang paling jelek.

\footnotetext{
${ }^{31}$ al-Qur'an, 18: 29.
} 
Mengenai permasalahan di atas tadi kita dapat memperhatikan sabda Rasulullah saw:

$$
\begin{aligned}
& \text { حدثنا عبد الله حدثنى أبى ثنا عبد الأعلى عن معمر عن الزهرى عن سعيد بن }
\end{aligned}
$$

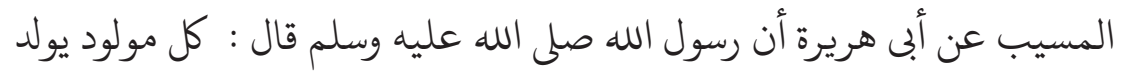

$$
\begin{aligned}
& \text { على الفطرة فأبواه يهودانه وينصرانه أو يمجسانه. }
\end{aligned}
$$

Dari Abu Hurairah ra, berkata: Rasulullah saw bersabda: Tidak ada seorang bayipun dilahirkan, kecuali ia dalam keadaan (dibekali) fitrah (instink ketuhanan/ketaubidan). Maka kemudian orang tuanyalah yang menyebabkannya menjadi Yahudi, Nasrani atau Majusi ...

Di sini jelas bahwa pendidikan akhlak anak oleh orang tua sangat berperan. Sebagaimana diketahui, bahwa pendidikan akhlak yang lebih mengena adalah dengan jalan orang tua memberikan teladan pada anakanaknya. Ketika orang tuanya saleh, insya Allah, berdasarkan hadis di atas, anak-anaknya akan menjadi saleh pula, yang mana kesalehan tersebut memang sudah ada pada diri orang tua sebelum memiliki anak, bahkan sebelum mereka menikah. al-'Adawi dalam pembahasannya bahkan menampilkan ayat a-Quran yang menunjukkan bahwa kesalehan orang tua akan besar pengaruhnya terhadap keturunannya :

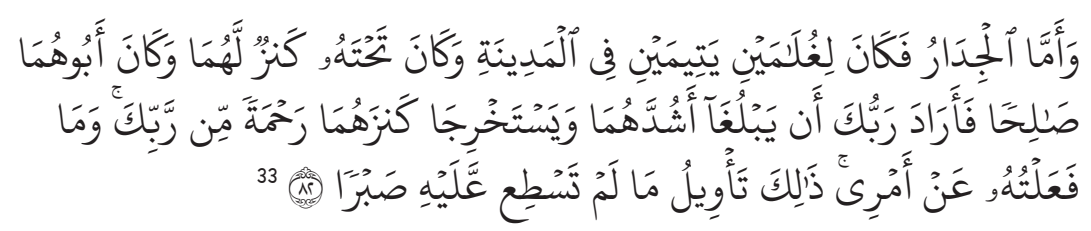

Adapun dinding itu adalah kepunyaan dua orang anak yatim di kota, dan di bawah dinding itu ada harta benda simpanan bagi mereka berdua, sedang ayahnya adalah seorang yang saleh, maka Tuhanmu menghendaki agar supaya mereka sampai kepada kedewasaannya dan mengeluarkan simpanannya itu, sebagai rahmat dari Tuhanmu; dan bukanlah aku melakukannya itu menurut kemauanku sendiri. Demikian itu adalah tujuan perbuatan-perbuatan yang kamu tidak dapat sabar terhadapnya".

\footnotetext{
${ }^{32}$ Ahmad ibn Hanbal Abu 'Abd Allah al-Shaibāniy, Musnad al-Imām Aḥmad ibn Hanbal, Juz 2 (Kairo: Mu’assasat Qurt\}ubah), 233.

33 al-Qur'an, 18: 82.
} 
Ayat ini secara tersirat menceritakan bagaimana orang yang saleh, memiliki dua orang anak yang kehidupan mereka diperhatikan oleh seorang nabi, yaitu nabi Khiḍir as, hingga bentuk perhatiannya hingga masalah ekonomi mereka berdua. Dapat dibayangkan kesalehan kedua anak ini hingga hidupnya diperhatikan oleh seorang nabi, apalagi nabi yang oleh kebanyakan orang di kalangan kita dianggap sebagai nabi yang masih hidup hingga sekarang dan selalu ditungu-tunggu kehadirannya karena hal-hal yang luar biasa yang dianugerahkan kepadanya, termasuk penguasaan ilmu laduni sekaligus wewenang mengajarkannya pada orang-orang yang dipilih Allah (biasanya para wali dan orang-orang saleh).

\section{F. Memilih Jodoh Yang Saleh/Salehah}

Salah satu usaha untuk mendapatkan keturunan yang berakhlak menurut al-Adawi adalah dengan jalan memilih jodoh yang shaleh/ shalehah. Istri salehah kelak akan mengajarkan kepada anak-anaknya alQuran, Sunnah Nabi saw, akhlak yang mulia, bisa membedakan perkara yang halal dan haram.

Makanya, sebelum pernikahan, peminangan disyari'atkan kepada calon suami dan istri, bertujuan agar satu sama lain saling mengenal secara baik terutama kepribadian masing-masing, keluarga, ekonomi dan keadaan fisiknya. Hal ini dimaksudkan agar kelak setelah perkawinan berlangsung tidak terjadi penyesalan yang disebabkan oleh kekurangan yang ada pada pasangannya.Tentu saja dampak penyesalan tersebut tidak baik terhadap kehidupan rumah tangga dan ini dapat memengaruhi pertumbuhan dan perkembangan jiwa anak yang lahir dari pernikahan mereka. Padahal perkawinan itu disyariatkan adalah untuk meneruskan dan melestarikan silsilah keturunan atau nasab. ${ }^{34}$

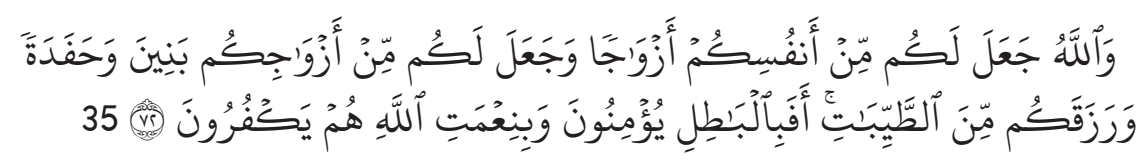

\footnotetext{
${ }^{34}$ Rahmana Ritonga, Aqidah; Merakit Hubungan Manusia Dengan Khaliknya Melalui Pendidikan Akidah Anak Usia Dini ( Surabaya : Amelia, 2005), 12.

${ }^{35}$ al-Qur'an, 16: 72.
} 
Allah menjadikan bagi kamu isteri-isteri dari jenis kamu sendiri dan menjadikan bagimu dari isteri-isteri kamu itu, anak-anak dan cucu-cucu, dan memberimu rezki dari yang baik-baik. Maka mengapakah mereka beriman kepada yang bathil dan mengingkari nikmat Allah?"

Ayat ini menegaskan bahwa tujuan utama perkawinan adalah untuk mendapatkan keturunan yang baik dan saleh yang membuat perkawinan itu lestari dan berkesinambungan secara tenteram. Untuk mencapai tujuan ini, Rasulullah saw membimbing umatnya dalam memilih pasangan ideal agar anak keturunan yang dihasilkan menjadi anak yang beriman dan berbudi luhur. Pemilihan pasangan ini hanya bisa dilaksanakan melalui peminangan. Salah satu petunjuk rasul untuk hal ini dapat dilihat dari hadis berikut:

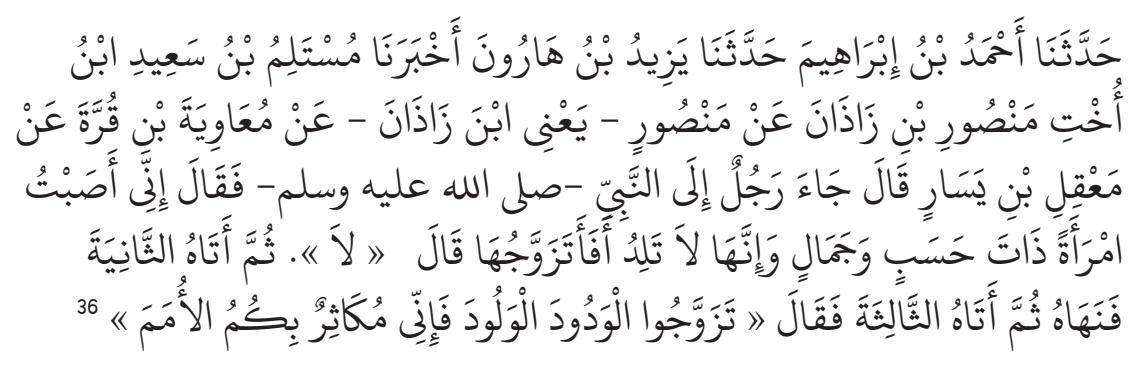

... Dari Mu'awiyyah bin Qurrah, dari Màqil bin Yasär, berkat: Pernah suatu ketika seorang laki-laki datang menemui Nabi saw, dan berkata: Sesungguhnya saya dipertemukan dengan wanita yang berderajatttinggi nasabnya dan cantik pula, hanya saja ia tidak bisa memberikan keturunan (mandul). Nabi saw, menjawab : Tidak. Kemudian laki-laki itu (pada kesempatan lain) datang untuk kedua kalinya (dengan pertanyaan yang sama). Nabi saw pun kembali melarangnya. Hingga pada (kesempatan berikutnya, yaitu) ke tiga, Nabi saw bersabda: Kawinilah wanita yang penuh kasih sayang dan juga (sekiranya nanti bisa) melahirkan banyak anak, karena aku kelak akan membanggakan jumlah kalian di depan umat-umat yang lain.

Karena salah satu tujuan perkawinan adalah melestarikan keturunan, maka yang dikawini itu harus yang bisa melahirkan anak. Hal ini bisa diketahui dari ibu dan neneknya yang secara genetik dapat menunjukkan dapat menunjukkan keadaan anak keturunannya dalam hal mampu tidaknya

${ }^{36}$ Abū Dāwud Sulaimān ibn al-As'ath ibn Ishāq ibn Bashīr ibn Shadad ibn 'Amr al-Azdy alSajistāny, Sunan Abi Daud, Juz 2, 175. 
anak perempuan itu melahirkan keturunan. Agar anak yang dilahirkan itu dapat diharapkan keshalehannya, maka wanita yang dikawini harus juga yang shalehah. Kriteria wanita shalehah setidaknya bisa diukur dalam hadis berikut :

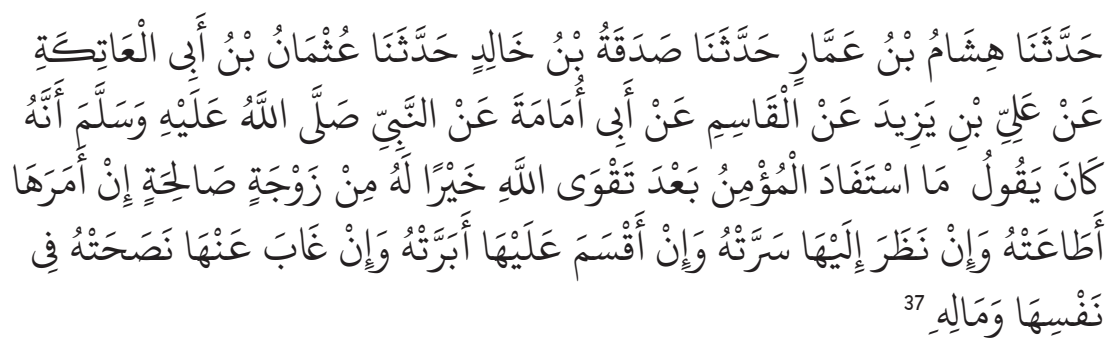

Seorang mukmin tidak dapat mengambil faedah yang lebih baik lagi setelah ketaqwannya kepada Allah, kecuali istri yang salehah, (yaitu seorang istri yang) apabila orang mukmin tadi(sang suami) memerintahnya ia mematuhinya, apabila suami memandangnya, ia bisa menyenangkannya, apabila suami bepergian, ia bisa menjaga dirinya dan hartla suaminya.

Jika istri seperti itu berada di rumah, maka apa yang dikatakan Rasulullah saw: Bayti jannati, Rumahku adalah sorgaku bisa menjadi kenyataan. Untuk mendapat pasangan yang shalehah seperti itu, maka dalam meminang pasangan harus diperhatikan empat hal seperti yang dijelaskan Rasulullah saw:

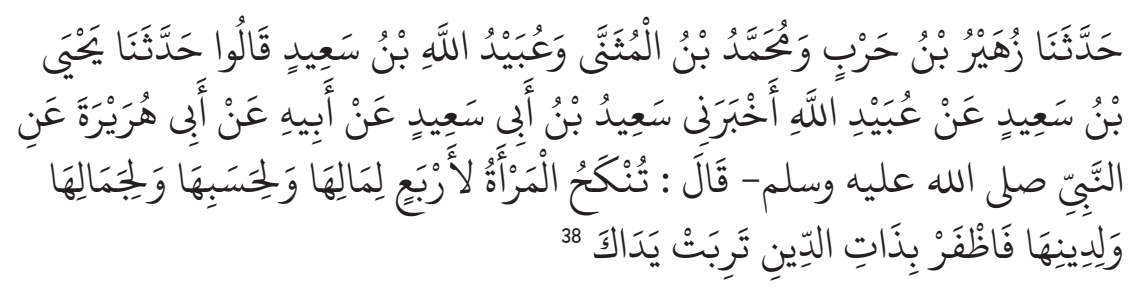

Wanita itu dinikahi dikarenakan empat hal, hartanya, keturunanya, kecantikannya dan agamanya. Piliblah yang mempunyai agama, maka engkau akan beruntung.

Dalam hadis di atas, bahwa prioritas dalam memilih istri adalah yang

${ }_{37}$ Ibn Mājah Abū 'Abd Allah Muh\}|ammad ibn Yazid al-Quzwainiy, Sunan Ibn Mājah, Juz 5, 454.

${ }^{38}$ Muslim ibn Hujjāj Abū Ḥasan al-Qushairiy al-Naisābūriy, Șahīh Muslim , Juz 7, 388. 
wanita yang agamanya terpelihara atau salehah. Adapun 3 sifat yang lain, adalah nilai plus dari salehah.

Pada kesempatan lain Rasulullah mengingatkan bahwa keturunan memilki pengaruh yang kuat dalam membentuk anak yang saleh. Oleh karena itu Rasulullah menyuruh menikahi wanita yang berasal dari keturunan yang mulia, terhormat dan baik-baik. Terkait dengan hal ini bersabda lagi:

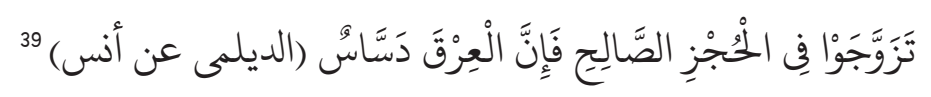

"Nikahilah wanita yang baik, karena sesungguhnya keturunan (tabiat ibunya) memiliki pengaruh yang kuat.”

Dengan demikian semakin nyata hikmah mengapa umat Islam dilarang Allah mengawini orang-orang musyrik, karena perkawinan itu akan melahirkan keturunan yang berperilaku musyrik. Mengawini wanita yang taat beragama dimaksudkan agar ia melahirkan anak-anak yang berbudi luhur dan berakhlak mulia.

Keharusan memilih pasangan seperti dianjurkan Rasulullah dipandang sebagai kebenaran ilmiah dan sesuai dengan pandangan paedogogis pada abad modern ini. Ilmu yang membahas tentang heriditas (keturunan) telah menetapkan bahwa anak akan mewarisi tabiat dari kedua orang tuanya sejak masa kelahirannya.

Usaha inilah merupakan langkah yang paling awal dalam membina anak yang berakidah dan berakhlak. Apabila suatu pekerjaan dimulai dengan yang benar dan baik maka hasilnya pun akan benar dan baik, sebaliknya pekerjaan yang dimulai dengan cara yang tidak baik, maka hasilnya ( anak keturunan) tidak baik. Kondisi ini dapat dianalogikan dengan apa yang disabdakan Nabi saw:

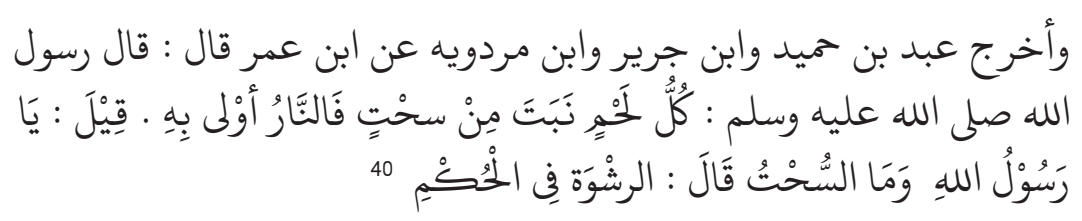

${ }^{39}$ Jalāluddin al-Suyūt\}i, Jāmi' al-Aḥādith, Juz 11, 259.

40 'Abd al-Raḥmān ibn Abi Bakr, Jalāluddin al-Suyūṭi, al-Dur al-Manthūr fì Tảwül bi alMàthür, , Juz 3, 382. 
..dari Ibn 'Umar, dia berkata: Rasulullah saw pernah bersabda: Setiap daging yang tumbuh dari suht, maka nerakalah yang pantas untuknya. Ditanyakan," Ya Rasulallah, apa itu suht itu? Nabi saw pun menjawab: "Suap-menyuap dalam hukum."

Berdasar hadis di atas, dapat pula ditarik pemahaman bahwa setiap janin yang tumbuh dari hasil hubungan laki-laki perempuan, jika dalam jasad salah satu dari mereka atau keduanya sebelum berhubungan memang sudah terkandung barang yang haram, atau sedang dalam murka Allah dan belum bertaubat, maka ketika dari hubungan itu akhirnya mempunyai anak, maka akhlak atau tabiat dari anak tersebut dikhawatirkan akan menjadi tercela. Apalagi jika selama masih dalam kandungan, sang calon ibu terus mengkonsumsi barang yang haram, maka akan lebih dikhawatirkan lagi keadaan akhlak anaknya kelak. Wal ‘iyazzu billāh. Di sini jelas bahwa memilih jodoh yang saleh/ salehan adalah sangat penting. Karena kesalehan akan "menuntun" seseorang berhati-hati dalam memilih apa yang akan dikonsumsinya sehari-hari.

Senada dengan hal ini, Husain Maẓāhiri, ulama asal Iran berpendapat, apabila nuthfah terbentuk dari barang yang haram, maka hal itu merupakan lahar subur bagi penderitaan dan kesengsaraan anak. Sedangkan makanan halal menjadi lahan subur bagi masa depan yang bahagia dan tenang. ${ }^{41}$

Rasulullah saw pernah mengasingkan diri dari manusia selama 40 hari untuk bertahannuth di gua Hira. Rasulullah meminta istrinya, Khadijah ra untuk mengasingkan diri juga dari manusia dan tetap berada di rumah untuk beribadah serta melarang siapapun masuk ke rumah beliau. Setelah masa pengasingan berakhir, Rasulullah saw mengetuk pintu rumah Khadijah ra, dan Jibril datang dengan membawa hidangan dari surga. Jibril meminta keduanya memakan sendiri dan tiada seorangpun boleh menyentuhnya, dan keduanya tidak boleh makan sesuatu setelahnya hingga selesai hubungan intim antara mereka dan terbentuk nutfah. Khadijah ra berkata," Setelah Rasulullah saw meninggalkan tempat tidurnya, aku merasakan cahaya janin dalam perutku,".Demikianlah nuthfah Fatimah al-Zahra terbentuk. Peristiwa bersejarah ini menyingkap secara dalam tentang pengaruh yang dalam pada makanan halal dan makanan haram terhadap perjalanan nasib seorang

${ }^{41}$ Husain Maz̄āhiri, Tarbiyyat al-Tifl fial-Ru'yat al-Islämiyyah (Beirut: Muassasah al-Bi'thah, 1992), 73. 
anak. Makanan haram membuka jalan bagi anak menuju kesengsaraan dan penyimpangan, sedangkan makanan halal berlaku sebaliknya. ${ }^{42}$

\section{G. Melindungi Anak Sebelum Dilahirkan}

Cara melindungi anak sebelum kelahiran adalah berdo'a sebelum masuk kamar pengantin, saat pernikahan dan berdoa ketika hendak jima'. Disunnahkan setelah akad nikah untuk masuk ke tempat istri, memegang ubun-ubunnya dan berdo'a:

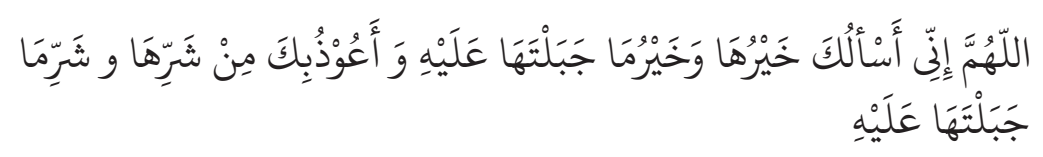

Ya Allah, aku memohon kepada-Mu kebaikan istriku dan kebaikan yang Engkau ciptakan kepadanya dan aku berlindung dari kejelekannya dan kejelekan yang Engkau ciptakan kepadanya." (HR. Abu Dawud dengan sanad Hasan dari Amr bin Syu'aib dari ayahnya dari Nabi saw bersabda," Bila salah seorang dari kalian membeli seorang budak, hendaklah ia mengucapkan.... hadis di atas)

Ketika mendatangi isri (jima') dianjurkan membaca do'a:

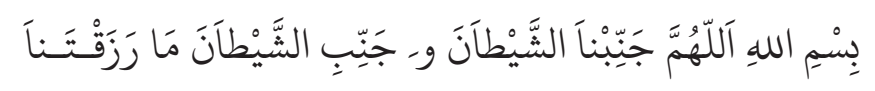

Dengan nama Allah, Ya Allah jaubkanlah kami dari syetan dan jaubkanlah syetan dari anak yang akan Engkau anugerahkan kepada kami."

Beliau saw juga bersabda yang artinya," Bila kalian membaca doa tersebut ketika hendak mendatangi istri kemudian mempunyai anak, syetan tidak bisa memberi bahaya selamanya." 43

Doa tersebut di atas, dengan izin Allah, berfungsi melindungi anak dari setan. Sayangnya banyak orang yang meremehkan dan mengabaikan hal ini, sehingga bisa jadi inilah yang menyebabkan banyaknya orang

${ }^{42}$ Ibid.

${ }^{43}$ Lihat di : Abu al-Fidä’ Ismǟil ibn 'Umar Ibn Kathir al-Qurāshiy al-Dimshiqiy, Tafsīr Ibn Kathìr, Juz 5( Dār T\}ayyibah, tt), 95:

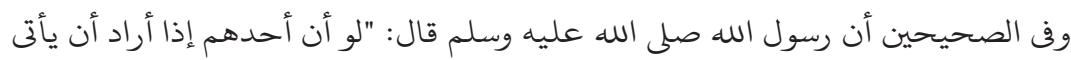

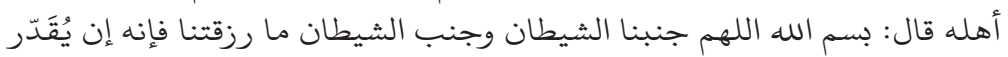

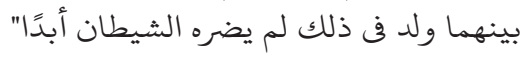


yang dikuasi oleh setan sehingga mereka keluar dari norma agama, rusak akidah dan akhlaknya, dan lain sebagainya. ${ }^{44}$ Suami istri ketika hendak berhubungan intim tidak menyebut nama Allah, maka setan akan ikut serta dalam pembentukan nut\}fah. Apalagi jika berhubungan itu disertai hal-hal yang mengandung dosa, maka kiranya lebih dalam lagi setan ikut menyertai nuthfah itu bahkan sampai nutfah itu kelak menjadi manusia.

Riwayat menyatkan bahwa Hajjaj bin Yusuf, seorang tirani kejam dan lalim adalah seseorang yang disertai setan. Sejarah mencatat bahwa ia mempunyai seorang ibu yang sebelum melahirkannya adalah seorang wanita yang mengejar kenikmatan, dan ia tergila-gila kepada pemuda Nasher bin al-Hajjaj yang terkenal dengan ketampanannya waktu itu. Hingga suatu hari Khalifah Umar bin Khattab berjalan dan mendengar seorang wanita yang telah bersuami, tengah mendendangkan syair cinta yang berisi pujian kepada Nasher bin al-Hajjaj dan menginginkan hubungan dengannya. Maka sang Khalifah Umar mengirim seorang utusan kepada Nasher dan menggunduli kepalanya kemudian mengusirnya keluar dari Madinah. Suatu saat ketika terjadi hubungan intim antara wanita itu dengan suaminya, Yusuf al-Thaqafi, khayalan wanita ini masih dipenuhi dengan bayangan Nasher, lelaki yang haram dicintainya. Meskipun wanita itu melakukan hubungan intim dengan suaminya (Yusuf), namun jiwa, khayalan dan pikirannya selalau mengarah pada Nasher yang ia cintai. Dari hubungan itu lahirlah bayi lelaki. Selanjutnya anaknya tersebut diberi nama: Hajjaj, mengambil nama dari Nasher bin Hajjaj, pria idolanya. Anaknya ini kemudian tumbuh dewasa dan menjadi raja dengan perangai yang sangat buruk. Kitab-kitab sejarah menegaskan bahwa Hajjaj bin Yusuf ini telah membantai 120.000 muslimin termasuk didalamnya puluhan sufi demi menjaga kedudukan 'Abd al-Malik bin Marwan. ${ }^{45}$

Maka dalam hubungan intim suami istri, harus mendapat perhatian khusus. Karena ini adalah merupakan awal mulanya sebuah kehidupan baru dengan segala nasibnya. Termasuk menjauhkan diri dari setan, adalah membuang segala hal yang mengandung unsur-unsur syaițanizyah seperti pikiran-pikiran negatif dan perasaan-perasaan yang mengakibatkan tekanan psikis. Dengan kata lain, dalam berhubungan, selain kondisi fisik yang

\footnotetext{
${ }^{44}$ 'Abd al-Azizz ibn Fath\} al-Sayyid Nada, Ensiklopedia Etika Islam, 335.

${ }^{45}$ Husain Maz̄āhiri, Tarbiyyat al-Ṭifl, 71-72.
} 
prima juga dibutuhkan pikiran dan perasaan positif. Hal ini karena di dunia ini berlaku hukum sebab akibat. Jika suami istri atau salah satu dari mereka ketika melakukan hubungan intim pada pikiran dan perasaannya memendam sesuatu yang buruk, maka hal ini sedikit banyak akan memengaruhi nut\}fah/benih yang tertanam dalam rahim.

R. M. Soewandi Budiono dalam Layang Pangrucutan (Buku Penyatuan) seperti yang dikutip oleh Budiono Herusatoto dan Suyadi Digdoatmadja dalam bukunya Seks Para Leluhur, menyebutkan beberapa contoh perasaan negatif saat hubungan intim beserta akibatnya sebagai berikut : ${ }^{46}$

1. Jika suami istri atau salah satu dari mereka ketika melakukan hubungan intim masih memenda rasa kecewa karena suatu hal yang terjadi atau kurang berminat dalam melakukannya, maka akan menyebabkan anak yang dilahirkan kelak mempunyai watak yang mudah kecewa (mudah patah semangat), sehingga akan menjadi anak yang sengsara hidupnya.

2. Jika suami istri atau salah satu dari mereka melakukan hubungan intim sedang memendam rasa amarah, maka rasa amarah itu akan berpengaruh dan tertanam pada benih (jawa: manikem) yang ditanamnya sehingga anak yang dilahirkannya kelak akan bersifat pemarah, dan akan celaka pula hidupnya.

3. Apabila mereka berdua atau salah satu dari mereka dalam melakukan nikah rohani tersebut ternyata dalam hati atau pikirannya terselip hal-hal lain yang menggoda, maka hal tersebut akan berpengaruh pada perwatakan anak yang akan dilahirkannya kelak. Bila godaan yang terlintas rasa atau pikiran itu dari pihak pria, maka yang terpengaruh adalah sifat atau budi pekerti dari benih/manikem calon anak perempuan, dan sebaliknya.

4. Jika yang terlintas dalam godaan rasa atau pikiran itu hal-hal yang baik, maka sifat yang baik tersebutlah yang akan tertanam dalam budi pekerti anak yang dilahirkan kelak, dan sebaliknya.

Hal-hal di atas mengingatkan penulis pada khutbah Ibn M as'ud ra:

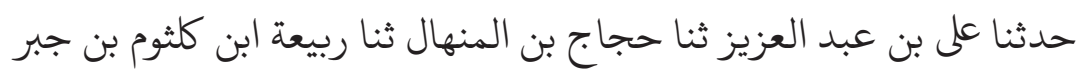

${ }^{46}$ Budiono Herusatoto dan Suyadi Digdoatmadja, Seks Para Leluhur-Merancang Keturunan Berkualitas Lewat Tata Senggama Ala Leluhur Jawa (Yogyakarta: TINTA, 2004), 86-88. 


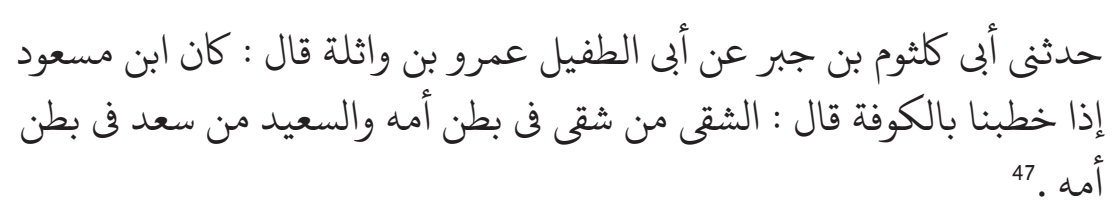

Dari Abu al-T\}ufail Amr bin Wathilah, dia berkata: Ibnu Mas'u>d ketika berkhutbah pad kami di Kuffah : Orang yang bahagia adalah orang telah berbahagia di perut ibunya, dan orang yang sengsara adalah orang yang telah sengsara di dalam perut ibunya.

Maksud dari kebahagiaan dan kesengsaraan semasa di perut ibu adalah bahwa kondisi ibu tersebut menciptakan potensi pada janin untuk menjadi bahagia atau sengsara di masa mendatang. Sebagian penyakit yang diidap ibu dapat menular pada anak sehingga ia lahir dengan penyakit bawaan yang ia sandang seumur hidupnya dan ini merupakan sebagian dari kesengsaraan hidup baginya. Atau sebaliknya, ia lahir sehat walafiat dan kesehatannya itu akan ia bawa selama hidupnya dan itu merupakan bagian dari kebahagiaannya.

Demikian pula halnya dengan kondisi spiritual, akhlak/moral dan kejiwaan, seperti kecemasan dan ketenangan, kerisauan dan kestabilan mental, ketakutan sebagaimana telah disebutkan beberapa di atas tadi, akan sangat berpengaruh pada anak.

Maka pemikiran al-'Adawi tentang usaha melindungi anak sebelum dilahirkan, sungguh merupakan hal yang sama sekali tidak boleh diabaikan.

${ }^{47}$ Sulaimān ibn Ah\}mad ibn Ayyūb Abu al-Qāsim al-Ṭabā>niy, al-Mujjam al-Kabīr, Juz 9 (Mosul: Maktabat al-'Ulum wa al-Hikam, 1983), 100. 


\section{DAFTAR PUSTAKA}

Al-Qur'an al Karim, Departemen Agama RI

Abu 'Abdillah Muștafā al-'Adawi , Figh Tarbiyyat al-Abnā' wa Ṭāifah min Nașāih al-Ațibbä' (Jeddah : Dār Mājid 'Asiri,1998)

Muh\}ammad Nawawi bin 'Umar al-Jawi al-Shafi'i, Fath al-Majìd fì Sharh al-Durr al-Farìd ( Dār Ihyā̄ al-Kutub al-'Arabiyyah).

M. Djamaluddin Achmad, K.H, "Hikmah ke-267", dalam Kajian Rutin Sharh al-H\}ikam li ibn Ațäillah al-Sakandary, Jombang, Senin, 27 April 2009.

Redaksi www.NUbatik.net - PCNU Kota Pekalongan, "Mengenal lebih dekat dengan pendiri Nahdlatul Ulama," dalam: http://www.nubatik. net/content/view/256/106/

Aḥmad ibn Hanbal Abu 'Abd Allah al-Shaibāniy, Musnad al-Imām Aḥmad ibn Hanbal, Juz 2 (Kairo: Mu’assasat Qurțubah).

Rahmana Ritonga, Aqidah; Merakit Hubungan Manusia Dengan Khaliknya Melalui Pendidikan Akidah Anak Usia Dini (Surabaya: Amelia, 2005).

Abū Dāwud Sulaimān ibn al-As'ath ibn Ishāa ibn Bashīr ibn Shadad ibn 'Amr al-Azdy al-Sajistāny, Sunan Abi Daud, Juz 2.

Ibn Mājah Abū 'Abdillah Muhammad ibn Yazid al-Quzwainiy, Sunan Ibn Mãjah, Juz 5.

Muslim ibn Hujjāj Abū Hasan al-Qushairiy al-Naisābūriy, Șahīh Muslim , Juz 7.

Jalāluddin al-Suyūṭi, Jāmi’ al-Aḥādith, Juz 11.

'Abd al-Rahmān ibn Abi Bakr, Jalāluddin al-Suyūṭi, al-Dur al-Manthūr fì Tàwīl bi al-Màthūr, Juz 3.

Husain Maẓāhiri, Tarbiyyat al-Tifl fì al-Ru'yat al-Islämiyyah (Beirut: Muassasah al-Bi'thah, 1992).

Abu al-Fidā' Ismāīl ibn 'Umar Ibn Kathir al-Qurāshiy al-Dimshiqiy, Tafsīr Ibn Kathìr, Juz 5 (Dār Țayyibah, tt).

'Abd al-'Azīz ibn Fath al-Sayyid Nada, Ensiklopedia Etika Islam.

Budiono Herusatoto dan Suyadi Digdoatmadja, Seks Para LeluhurMerancang Keturunan Berkualitas Lewat Tata Senggama Ala Lelubur Jawa (Yogyakarta: TINTA, 2004). 
Pemikiran Al 'Adawi Tentang Pendidikan Akhlak Anak ...

Sulaimān ibn Aḥmad ibn Ayyūb Abu al-Qāsim al-Ṭabrāniy, al-Mưjam alKabir, Juz 9 (Mosul: Maktabat al-'Ulum wa al-Hikam, 1983). 
